\title{
SEBARAN KEBIASAAN MEROKOK PADA PASIEN STROKE ISKEMIK YANG DI RAWAT INAP DI BAGIAN NEUROLOGI RSU PROF. DR. R. D. KANDOU MANADO
}

\author{
${ }^{1}$ Pricyllia Tumeleng \\ ${ }^{2}$ Theresia Runtuwene \\ ${ }^{2}$ Mieke Kembuan
}

\author{
${ }^{1}$ Kandidat Skripsi Fakultas KedokteranUniversitas Sam Ratulangi Manado \\ ${ }^{2}$ Bagian Neurologi Fakultas KedokteranUniversitas Sam Ratulangi Manado \\ Email: pricylliaveronika@yahoo.com
}

\begin{abstract}
Stroke is the number one cause of disability and number two cause of death in the world. This disease has now become a serious health problem and is more common in developing countries. The increasing incidence of stroke is closely related to smoking as a lifestyle for most people. Smokers increase the risk of stroke by two to four times compared with those who did not smoke. This study aims to determine the distribution of the smoking habit frequency in ischemic stroke's patients. This is a descriptive study. The population in this study are all ischemic stroke patients hospitalized in neurology department of Prof. Dr. R. D. Kandou hospital on November to December 2014 with a total sample of 42 patients with ischemic stroke. The results showed that most patients are male which there are 25 patients ( $59.5 \%$ ), most of the patients are aged 46-55 years and 56-65 years were 13 patients ( $31 \%$ ), $57.1 \%$ of patients as active smokers and $42.9 \%$ are passive smokers, $83.4 \%$ of patients with smoking duration $>5$ years, $70.8 \%$ of patients smoked $11-20$ cigarettes per day, $66.7 \%$ of patients taking cigarettes filters, and $97.6 \%$ had other risk factors other than smoking . Health workers are expected to provide counseling about the dangers of smoking, especially for those at risk of stroke.
\end{abstract}

Keywords: ischemic stroke, smoking

\begin{abstract}
Abstrak: Penyakit stroke adalah penyebab cacat nomor satu dan penyebab kematian nomor dua didunia. Penyakit ini kini telah menjadi masalah kesehatan yang serius dan lebih sering terjadi di Negara-negara berkembang. Meningkatnya angka kejadian stroke berhubungan erat dengan merokok sebagai gaya hidup pada sebagian besar orang. Perokok meningkatkan resiko terjadinya stroke hingga dua sampai empat kali dibandingkan dengan mereka yang tidak merokok. Penelitian ini bertujuan untuk mengetahui distribusi frekuensi kebiasaan merokok pasien stroke iskemik. Penelitian ini bersifat deskriptif. Populasi dalam penelitian ini adalah seluruh pasien stroke iskemik yang di rawat inap di bagian neurologi RSU Prof. Dr. R. D. Kandou periode November sampai Desember 2014 dengan jumlah sampel sebanyak 42 pasien stroke iskemik. Hasil penelitian menunjukkan jenis kelamin yang terbanyak laki-laki yaitu sebanyak 25 pasien (59,5\%), umur pasien sebagian besar 46-55 tahun dan 56-65 tahun sebanyak 13 pasien (31\%), sebanyak 57,1\% pasien sebagai perokok aktif dan 42,9\% sebagai perokok pasif, 83,4\% pasien dengan lama merokok $>5$ tahun, 70,8\% pasien merokok sebanyak 11-20 batang perhari, 66,7\% pasien mengkonsumsi rokok filter, dan 97,6\% memiliki faktor risiko lain selain merokok. Tenaga kesehatan diharapkan dapat memberikan konseling tentang bahaya rokok terutama bagi mereka yang berisiko terkena serangan stroke.
\end{abstract}

Kata kunci: stroke iskemik, merokok 
Stroke merupakan penyakit yang sering dijumpai pada masyarakat modern sekarang ini. WHO (World Health Organization) menetapkan bahwa stroke merupakan suatu sindrom klinis dengan gejala berupa gangguan fungsi otak secara fokal atau global yang dapat menimbulkan kematian atau kelainan yang menetap lebih dari 24 jam, tanpa penyebab lain kecuali gangguan vaskular. ${ }^{1}$ Stroke terbagi atas dua yaitu stroke hemoragik dan stroke non hemoragik (iskemik). Stroke non hemoragik adalah salah satu sindrom neurologi yang merupakan ancaman terbesar menimbulkan kecacatan dalam kehidupan manusia.

Stroke kini menjadi masalah yang cukup serius di dunia karena jumlah penderita stroke dan angka kematian serta kecacatan akibat stroke semakin bertambah setiap tahunnya. Data statistik dunia bersama WHO Tahun 2002-2006, menunjukkan 15 juta orang menderita stroke diseluruh dunia setiap tahun. Diperkirakan setiap tahun sekitar 500.000 orang penduduk Indonesia terkena serangan stroke. ${ }^{1}$ Badan kesehatan dunia American Heart Association memprediksi bahwa kematian akibat stroke akan meningkat seiring dengan kematian akibat penyakit jantung dan kanker kurang lebih enam juta pada tahun 2010 menjadi delapan juta di tahun $2030 .^{2}$ Di Indonesia data nasional menunjukkan bahwa stroke sebagai angka kematian tertinggi yaitu $15,4 \%{ }^{3}$

Stroke biasanya tidak berdiri sendiri, ada faktor yang mengakibatkan sampai pembuluh darah di otak mengalami penyumbatan atau pemutusan aliran darah. Penyebab yang terjadi berhubungan dengan faktor-faktor risiko yang dimiliki seseorang. Meningkatnya angka kejadian stroke, terutama stroke iskemik bukan hanya terjadi di negara maju saja, tapi juga menyerang negara berkembang seperti Indonesia. Hal ini berhubungan erat dengan kebiasaan mengkonsumsi rokok yang sudah menjadi gaya hidup yang kurang baik pada sebagian besar orang. ${ }^{4,5}$ Pada tahun 2002 Indonesia mengkonsumsi 182 milyar batang rokok menduduki peringkat ke lima konsumsi rokok setelah Cina, Amerika Serikat, Rusia, dan Jepang. Tobacco Atlas 2009 menunjukkan bahwa peringkat Indonesia pada tahun 2007 tetap pada posisinya yaitu peringkat ke lima (215 milyar batang). ${ }^{6,7}$

Di Indonesia, penelitian terbaru mengenai sebaran kebiasaan merokok sebagai faktor risiko terjadinya stroke iskemik masih jarang ditemukan oleh penulis baik dari jurnal maupun artikel kesehatan yang dipublikasikan. Oleh karena itu, penulis terdorong untuk melanjutkan penelitian yang telah ada pada pasien stroke iskemik yang dirawat inap di Bagian Neurologi RSUP Prof. Dr. R. D. Kandou Manado periode November sampai dengan Desember 2014.

\section{METODE PENELITIAN}

Penelitian ini adalah penelitian deskriptif dan dilakukan di bagian rawat inap neurologi RSU Prof. Dr. R. D. Kandou Manado selama bulan November sampai Desember 2014. Populasi target pada penelitian ini adalah seluruh pasien stroke iskemik yang di rawat inap di bagian saraf RSUP Prof. Dr. R. D. Kandou periode November sampai Desember 2014 dengan sampel yaitu penderita stroke iskemik yang memiliki kriteria inklusi di RSUP Prof. Dr. R. D. Kandou periode November sampai Desember 2014 sebanyak 42 pasien. Variabel pada penelitian ini terdiri dari jenis kelamin, umur, merokok, lama merokok, jumlah rokok yang dikonsumsi perhari, jenis rokok, tipe perokok dan faktor risiko lain yang dapat menyebabkan terjadinya stroke iskemik. Pengumpulan data dalam penelitian ini menggunakan kuesioner. Pengolahan data menggunakan SPSS

\section{HASIL PENELITIAN}

Berdasarkan hasil penelitian yang dilakukan terhadap pasien stroke iskemik di RSUP Prof. DR. R. D. Kandou periode November - Desember 2014 diperoleh data sebagai berikut:

A. Karakteristik Pasien 
Distribusi jenis kelamin pasien yang terbanyak adalah laki-laki sebanyak 25 pasien (59,5\%) dan perempuan sebanyak 17 pasien $(40,5 \%)$

Distribusi umur pasien yang terbanyak berkisar antara umur 46-55 tahun dan umur 56-65 tahun yaitu sebanyak 13 pasien $(31,0 \%)$

\section{B. Merokok}

Berdasarkan hasil penelitian ditemukan pasien stroke iskemik yang merokok sebanyak 24 pasien $(57,1 \%)$ dan yang tidak merokok sebanyak 18 pasien $(42,9 \%)$

Distribusi lama merokok pasien stroke iskemik yang terbanyak adalah $>10$ tahun yaitu sebanyak 20 pasien $(83,4 \%)$ dan yang paling sedikit adalah $<5$ tahun dan 5-10 tahun sebanyak 2 pasien (8,3\%)

Distribusi jumlah rokok terbanyak yang dikonsumsi perhari oleh pasien stroke iskemik adalah 10-20 batang perhari sebanyak 17 pasien (70,8\%) dan sisanya yang merokok $>20$ batang perhari sebanyak 6 pasien (25\%) dan $<10$ batang perhari sebanyak 1 pasien $(4,2 \%)$

Distribusi jenis rokok terbanyak yang dikonsumsi oleh pasien stroke iskemik yaitu rokok filter sebanyak 16 pasien $(66,7 \%)$ dan rokok kretek sebanyak 8 pasien $(33,3 \%)$

Distribusi tipe perokok pasien stroke iskemik yang terbanyak adalah perokok aktif yaitu sebanyak 24 pasien (57,1\%) dan perokok pasif sebanyak 18 pasien (42,9\%)

Distribusi pasien stroke iskemik yang memiliki faktor risiko lain selain merokok yaitu sebanyak 41 pasien (97,6\%)

\section{BAHASAN}

Karakteristik responden

a. Jenis kelamin

Berdasarkan hasil penelitian, jenis kelamin dibagi menjadi laki-laki dan perempuan. Distribusi frekuensi jenis kelamin terbanyak adalah laki-laki, yaitu sebanyak 25 pasien (59,5\%). Data ini sesuai dengan penelitian dari Handayani
(2012) yang menyatakan bahwa angka serangan stroke lebih sering terjadi pada laki-laki. $^{8}$

\section{b. Umur}

Berdasarkan hasil penelitian, pengelompokkan umur didasarkan pada kategori umur menurut depkes RI. Distribusi umur responden terbanyak adalah berkisar antara umur 46-55 tahun dan umur 56-65 tahun, yaitu masingmasing sebanyak 13 pasien (31,0\%). Dari 13 pasien pada kelompok umur 46-55 tahun ditemukan ada 8 pasien yang merokok dan pada kelompok umur 56-65 tahun ditemukan ada 5 pasien yang merokok. Data ini sesuai dengan data dari Aliah dkk (2007) yang menyatakan bahwa sebagian besar kasus stroke iskemik dijumpai pada orang-orang yang berusia diatas 40 tahun. $^{9}$

\section{B. Merokok}

Merokok merupakan salah satu faktor risiko penyebab terjadinya stroke iskemik. Dari 42 pasien stroke iskemik, didapatkan pasien stroke iskemik sebagai perokok aktif sebanyak 24 pasien $(57,1 \%)$ dan perokok pasif sebanyak 18 pasien (42,9\%). Data ini sesuai dengan penelitian Ovina dkk (2013) yang menyatakan bahwa adanya hubungan antara merokok dengan terjadinya stroke iskemik. Merokok dapat meningkatkan risiko terjadinya stroke sampai 2 hingga 4 kali dibandingkan dengan mereka yang tidak merokok. ${ }^{10}$

Dari 24 pasien yang merokok, didapatkan lama merokok pasien yang terbanyak adalah $>10$ tahun yaitu sebanyak 20 pasien $(83,4 \%)$ dan jumlah rokok perhari yang paling sering dikonsumsi oleh pasien stroke iskemik adalah 10-20 batang perhari sebanyak 17 pasien (70,8\%) sedangkan pasien yang merokok lebih dari 20 batang perhari lebih sedikit yaitu sebanyak 6 pasien (25\%). Data ini sesuai dengan penelitian Marisa (2012) yang menyatakan bahwa seseorang yang telah merokok $>10$ tahun berisiko 4 kali lebih besar terkena serangan stroke dibandingkan dengan mereka yang merokok kurang dari 
10 tahun, dan mereka yang merokok 11-20 batang perhari berisiko 2,5 kali untuk terjadinya stroke. Jumlah rokok yang dihisap akan memberi pengaruh yang sangat besar terhadap kejadian aterosklerosis terutama pada pembuluh darah otak sebagai pemicu stroke. Semakin lama dan banyak seseorang merokok menunjukkan semakin banyaknya bahan berbahaya dari rokok yang telah masuk kedalam tubuh. ${ }^{11}$ Jumlah rokok yang dihisap perhari memiliki hubungan yang erat dengan lama merokok seseorang. Orang yang merokok 11-20 batang perhari dengan lama merokok $>10$ tahun lebih berisiko terkena serangan stroke iskemik dibandingkan dengan orang yang merokok $>20$ batang perhari dengan lama merokok $<10$ tahun.

Jenis rokok terbanyak yang dikonsumsi oleh pasien stroke iskemik yaitu rokok filter sebanyak 16 pasien (66,7\%). Hal ini sesuai dengan penelitian Saleh (2007) yang menyatakan bahwa pasien stroke iskemik yang merokok lebih dominan menggunakan jenis rokok filter. Namun pada penelitian ini didapatkan bahwa jenis rokok tidak memiliki hubungan dengan terjadinya stroke iskemik. $^{12}$ Sebagian besar pasien stroke iskemik memiliki faktor risiko lain selain merokok yaitu sebanyak 41 pasien (97,6\%). Faktor risiko yang ditemukan antara lain usia, jenis kelamin, hipertensi, diabetes mellitus, penyakit ginjal dan asam urat, namun yang tersering adalah hipertensi dan diabetes mellitus. Data ini sesuai dengan penelitian Burhanuddin (2012) yang menyatakan bahwa ada faktor risiko lain seperti hipertensi diabetes mellitus yang dapat meningkatkan risiko terjadinya stroke iskemik. $^{13}$

\section{SIMPULAN}

Berdasarkan hasil penelitian dan pembahasan, maka dapat diambil kesimpulan bahwa pasien stroke iskemik dibagian Neurologi RSUP Prof. DR. R. D. Kandou lebih banyak pada laki-laki (59,5\%) dan paling banyak terkena serangan stroke pada umur 46-65 tahun
(31,0\%), sebagian besar pasien stroke iskemik merokok $(57,1 \%)$, lama merokok yang paling banyak ditemukan pada pasien stroke iskemik adalah $>10$ tahun (83,4\%), jumlah rokok perhari yang sering dikonsumsi pasien stroke iskemik adalah 10-20 batang perhari (70,8\%), jenis rokok yang paling sering dikonsumsi oleh pasien stroke iskemik adalah rokok filter (66,7\%), perokok aktif lebih sering terkena serangan stroke ikemik $(57,1 \%)$, pasien stroke iskemik memiliki faktor risiko lain selain merokok $(97,6 \%)$

\section{SARAN}

Berdasarkan kesimpulan tersebut, maka dapat diberikan saran bahwa setiap tenaga kesehatan diharapkan dapat memberikan konseling tentang bahaya rokok terutama bagi mereka yang berisiko terkena serangan stroke, masyarakat yang merokok harus menyadari bahaya rokok sebagai faktor risiko terjadinya stroke, masyarakat yang tidak merokok dapat mengingatkan bahaya merokok pada keluarga dan kerabat dekat serta tidak terpengaruh untuk ikut merokok

\section{DAFTAR PUSTAKA}

1. World Health Organization. The Who Stepwise Approach To Stroke Surveillance. 2009 [cited 2014 Sep 8]. Available from http://www.who.int/chp/steps/stroke/en /index.html

2. American Heart Association. Stroke Risk Factor. 2010 [cited 2014 Sep 8]. Available from http://www.strokeassociation.org/prese nter.html

3. Lumbantobing,S.M. Stroke Bencana Pendarahan Otak. Jakarta : FKUI; 2007. h. 2.

4. Goldstein LB, Bushnell CD, Adams RJ, Appel LJ, Braun LT, Chaturvedi Creager MA, et al. Guidelines for the primary prevention of stroke. On behalf of the American Heart Association Stroke Council. 2011;42:517-584.

5. Shah RS, Cole JW. Smoking and stroke: the more you smoke the more you stroke. Expert Rev Cardiovasc Ther. 
2010;8:917-932.

6. Hainawati,S. Editor Profil Kesehatan Indonesia. Jakarta: Departemen Kesehatan Indonesia; 2009.

7. Sugito, J. Stop Rokok, Jakarta: Swadaya; 2007. h. 6

8. Handayani. Angka Kejadian Serangan Stroke pada Wanita Lebih Rendah daripada Laki-Laki [skripsi]. Semarang: Fakultas keperawatanUniversitas Diponegoro 2012.

9. Aliah A, Kuswara F F, Limoa A, Wuysang G. Gambaran umum tentang gangguan peredaran darah otak dalam Kapita selekta neurology cetakan keenam editor Harsono. Gadjah Mada university press, Yogyakarta. 2007. h. 81-115

10.Ovina. Hubungan Pola Makan, Olahraga dan Merokok Terhadap Prevalensi Penyakit Stroke Non Hemoragik [skripsi]. Jambi: Fakultas Kedokteran dan Ilmu Kesehatan-Universitas Jambi 2013.

11.Marisa. Hubungan Perilaku Merokok dengan Kejadian Stroke di Bagian Saraf RSU Dokter Soedarso Pontianak Periode Juni-Juli 2012 [skripsi]. Pontianak: Fakultas Kedokteran-Universitas Tanjungpura 2012.

12.Saleh. Faktor Risiko Kebiasaan Merokok Terhadap Kejadian Stroke di Rumah Sakit Umum Daerah Bau-Bau Provinsi Sulawesi Tenggara Tahun 2007 [skripsi]. Kendari: Fakultas Kedokteran-Universitas Haluoleo 2007.

13.Burhanuddin M. Faktor Risiko Kejadian Stroke pada Dewasa Awal di Kota Makassar Tahun 2010-2012 [skripsi]. Makassar: Fakultas Kesehatan Masyarakat-Universitas Hasanudin 2012. 